\title{
ANALISIS PENERIMAAN DAN PENGGUNAAN TEKNOLOGI (UNIFIED THEORY OF ACCEPTANCE AND USE OF TECHNOLOGY) TUTORIAL ONLINE MAHASISWA PROGRAM S1 PGSD DAN S1 PGPAUD UNIVERSITAS TERBUKA
}

\author{
Windra Irawan \\ Nur Asiah \\ Mody Gayes Tuliabu \\ Universitas Terbuka \\ e-mail: windra@ecampus.ut.ac.id
}

\begin{abstract}
The online tutorials for undergraduatestudents at Universitas Terbuka has 30\% of contributions to the grade of the final exam, which is why students are expected not to depend solely on independent learning without any supporting facilities. With 339 undergraduate students of SIPAS NON-TTM PGSD and PGPAUD, the researcher used the unified theories of acceptance and use of technology to analyze students acceptance and technology usage, and using multiple regression as the statistical tools to test out the influence of performace expectancy, effort expectancy, social influence, and facilitating conditions towards the behavioral intention of undergraduate students of PGSD and PGPAUD in using online tutorials. It was found that facilitating conditions had the most significant influence towards behavioral intention, while performance expectancy was right after. Lower influence was found in social influence, while the effort expectancy doesn't have any significant effect on behavioral intention of undergraduate students of PGSD and PGPAUD in using online tutroials.
\end{abstract}

Keywords: acceptance and use of technology, UTAUT, S1 PGSD and PGPAUD, online tutorial

\section{PENDAHULUAN}

Universitas Terbuka (UT) untuk membantu mahasiswa dalam proses belajar dalam sistem pendidikan jarak jauh, menyediakan berbagai lanyanan bantuan belajar. Salah satu modus bantuan belajar adalah tutorial online . Saat ini semua mahassiwa UT dapat mempunyai hak mengikuti tutorial online (tuton) di http://elearning.ut.ac.id.

Layanan tuton tidak menpersyaratkan mahasiswa untuk membentuk kelas atau kelompok belajar yang berjumlah minimal 20 mahasiswa. Sehingga program ini dirancang agar mahasiswa dapat tetap mengikuti pendidikannya dengan bantuan belajar tanpa harus hadir di kelas, tetap secara online atau melalui jaringan internet.

Penyelenggaraan tutorial online semakin menjadi penting setelah dibukanya Paket Non Tutorial Tata Muka (NonTTM) pada program studi S1 PGSD dan PGPAUD sejak masa registrasi 2017.2 (2017/2018.1). Hingga saat ini jumlah mahasiswa yang mengikuti program ini terus bertambah. Berikut ini adalah jumlah mahasiswa program S1 PGSD dan PGPAUD (Pendidikan dasar 
= Pendas) yang mengikuti program SIPAS non TTM. Pada masa 2017/2018.2 sudah 24 UPBJJ yang menyelenggarakan S1 Pendas Non TTM, dengan jumlah mahasiswa sekitar 2.225 orang.

Bagi mahasiswa S1 PGSD/PAUD Sipas Non TTM, untuk mengikuti bantuan tutorial online merupakan hal yang baru. Sehingga dibutuhkan adaptasi dan kemampuan menerima teknologi dari mahasiswa. Dengan adaptasi dan proses penerimaan teknologi yang baik, maka mahasiswa dapat mengikuti tutorial online dengan maksimal dan membantu proses pembelajaran selama studi di Universitas Terbuka. Padahal Wardoyo \& Karyanto (2011) menyebutkan bahwa untuk mahasiswa Non Pendidikan Dasar tingkat, disebutkan bahwa tingkat pemanfaatan sumber belajar online (termasuk didalamnya tutorial online) oleh mahasiswa UT program nonpendas masih rendah. Sehingga inilah yang menjadi alasan utama dari penelitian penggunaan teknologi tutorial online oleh mahasiswa pendas.

Menurut Pacey (2000), bahwa teknologi bukan sekedar alat yang dapat meningkatkan nilai kehidupan manusia. Teknologi memiliki aspek yang tidak sekedar peralatan keras (hardware) namun juga budaya, organisasi, dan teknis. Untuk menerima sebuah teknologi dibutuhkan beberapa tahapan diantaranya adalah yang disebutkan Rogers (2003), yaitu: pengetahuan (knowledge), Persuasi (persuation), keputusan (decision), penerapan (implementation), dan tahap konfirmasi (confirmation).

Sebuah model penelitian yang seringkali digunakan untuk melihat penerimaan penggunanya adalah Technology Acceptance Model (TAM). Analisa dengan teori TAM bertujuan menjelaskan serta memperkirakan penerimaan pengguna terhadap suatu teknologi. Teori ini menyediakan perangkat analisa untuk melihat faktor-faktor yang mempengaruhi penerimaan terhadap suatu teknologi. Teori ini bermula dari Theory of Reasoned Action ang perkenalkan oleh Fishbein dan Ajzen (1980). Kemudian, Vinkatesh (2003) menyatukan berbagai teori dalam penggunaan teknologi informasi dalam sebuah model khusus yang kemudian disebut unified theorie of acceptance and use of thecnology (UTAUT).

UTAUT merupakan sebuah model analisis untuk menjelaskan perilaku pengguna terhadap sebuah teknologi. Model ini berusaha menganlisa bahwa niat perilaku (behavioral intention) dan perilaku untuk menggunakan suatu teknologi (use behavior) dipengaruhi harapan kinerja (performance expectancy), harapan usaha (effort expectancy), pengaruh sosial (social influence), dan kondisi pendukung (facilitating conditions). Keempat Faktor tersebut dimoderasi oleh faktor jenis kelamin (gender), usia (age), pengalaman (experience) dan kesukarelaan menggunakan (voluntariness of use). Berbagai penelitian yang mengadopsi model ini telah sering dilakukan, dengan hasil temuan yang beragam (Handayani, 2017).

Dari latar belakang di atas, maka permasalahan yang akan dibahas pada artikel ini adalah bagaimana harapan kinerja (performance expectancy), harapan usaha (effort expectancy), pengaruh sosial (social influence), dan fasilitas pendukung (facilitating conditions) mempengaruhi niat perilaku (behavioral intention) menggunakan tutorial online.

\section{Kajian Teori Tutorial Online}

Tuton bagi mahasiswa UT memiliki kontribusi sebesar 30\% terhadap nilai ujian akhir semester (kecuali pascasarjana yang berkontribusi $(50 \%)$. Sehingga dengan kontribusi ini diharapkan mahasiswa tidak hanya mengandalkan belajar mandiri tanpa bantuan belajar yang disediakan.

Dalam tutorial online terdiri dari 8 inisiasi, dengan 3 kali tugas pada pertemuan ke-3, 5, dan 7. Pada masing-masing inisiasi juga disediakan forum diskusi bagi mahasiswa terhadap 
permasalahan yang berkaitan dengan inisiasi atau masalah aktual yang berhubungan dengan pembahasan. Sebelum mengikuti tutorial online mahasiswa harus terlebih dahulu melakukan aktivasi untuk pertama kalinya dengan menggunakan email masing-masing mahasiswa.

Fakultas di Universitas Terbuka terdiri dari Fakultas Ekonomi (FE), Fakultas MIPA (FMIPA), Fakultas Hukum, IImu Sosial dan IImu Politik (FHISIP) dan Fakultas Keguruan dan IImu Pendidikan (FKIP). Khusus untuk mahasiswa FKIP terdapat program pendidikan dasar, yaitu S1 PGSD dan S1 PGPAUD. Kedua program pendidikan dasar ini sampai sekarang masih memiliki jumlah mahasiswa yang lebih besar dari program lain dari semua fakultas. sehingga hingga 2018.1 pengelolaan termasuk kalender akademik di UT terbagi; kalender akademik Non Pendas, Pendas, dan Pascasarjana.

Skema layanan non TTM bagi mahasiswa Pendas ini, mengharuskan mahasiswa untuk belajar secara mandiri melalui buku materi pokok (BMP) dan bahan ajar digital. Selain itu mahasiswa mendapatkan layanan bantuan belajar jarak jauh antara lain: tutorial online (tuton) ruang baca virtual (RBV), latihan mandiri (LM) online, Guru Pintar Online(GPO), dan lainya. Khusus untuk layanan tutorial online matakuliah non praktik dan TAP, layanan tuton dapat diberikan dengan jumlah mahassiwa 150 orang per kelas. (Pedoman Sipas Non TTM FKIP Universitas Terbuka).

\section{Tecnology Acceptance Model (TAM) dan UTAUT}

Pada tahun 1989, Davis mengusulkan model penerimaan teknologi untuk menjelaskan potensi perilaku pengguna dalam menggunakan teknologi. TAM melibatkan dua prediktor utama yaitu persepsi kemudahan, persepsi penggunaan dan variabel dependen perilaku niat. TAM telah datang untuk menjadi salah satu model yang paling banyak digunakan dalam sistem informasi (King \& He, 2006).

Penelitian menggunakan TAM dianggap sebagai yang paling model populer dan kuat di penelitian sistem informasi, untuk menjelaskan atau memprediksi penerimaan individu terhadap berbagai skenario dan konteks organisasi berbasis teknologi komputerisasi. TAM berhipotesa bahwa persepsi manfaat pengguna (perceptions of usefulness) dan kemudahan penggunaan (ease-of-use) menentukan sikap untuk menggunakan sistem atau teknologi sedangkan sikap individu mempengaruhi niat perilaku untuk menggunakan teknologi, selanjutnya menyebabkan penggunaan teknologi terkini (Saeed, et al., 2010).

Penerimaan pengguna merupakan faktor yang menentukan kesuksesan atau kegagalan suatu teknologi diterima dalam organisasi (Davis, 1987). Hal tersebut terjadi karena keputusan individu atau organisasi untuk menggunakan atau tidak menggunakan suatu teknologi komunikasi akan berdampak pada kinerja perseorangan dan organisasi. Banyak faktor yang menjadi sebab penerimaan sebuah teknologi baik internal maupun eksternal. Kurangnya penerimaan seorang pengguna dapat menjadi faktor kegagalan adopsi teknologi komunikasi dalam organisasi yang akan berimbas pada tujuan penggunaan sistem dalam organisasi tidak akan tercapai (Davis, 1993).

Teori TAM merupakan salah satu teori utama dalam penyatuan teori yang kemudian disebut dengan Unified Theori of Acceptance and Use of Technology (UTAUT). UTAUT merupakan salah satu model penerimaan teknologi terkini yang dikembangkan oleh Venkatesh, dkk. (2003). Vinkatesh berusaha menyatukan delapan teori penerimaan teknologi satu teori tersendiri. Kedelapan teori taersebut terdiri daritheory of reasoned action (TRA), technology acceptance model (TAM), motivational model (MM), theory of planned behavior (TPB), combined TAM and TPB, model of PC utilization (MPTU), innovation diffusion theory (IDT), dan social cognitive theory (SCT). 
Kemudian Vinkatesh (2003) menyusun tujuh konstruk yang menjadi variabel langsung yang signifikan terhadap niat perilaku (behavioral intention) atau perilaku penggunaan (use behavior) dalam satu atau lebih di masing-masing model. Konstruk-konstruk tersebut yaitu harapan kinerja (performance expectancy), Harapan usaha (effort expectancy), Pengaruh sosial (social influence), Kondisi fasilitas (facilitating conditions), dansikap terhadap penggunaan teknologi (attitude toward using technology).

Ditemukan bahwa empat konstruk utama memainkan peran penting sebagai determinan langsung dari behavioral intention dan use behavior yaitu performance expectancy, effort expectancy, social influence, dan facilitating conditions. Sedangkan yang lain tidak signifikan sebagai determinan langsung dari behavioral intention. Disamping itu terdapat pula empat moderator: jenis kelamin, usia, kerelaan, dan pengalaman diposisikan untuk memoderasi dampak dari empat konstruk utama pada behavioral intention dan use behavior (Sedana, 2009).

Namun dalam penelitian ini kekhawatiran akan terjadinya bias pada hasil penelitian, maka variabel mederator tidak digunakan. Contoh adalah usia, sebagaimana diketahui bahwa mahasiswa pendas adalah mahasiswa yang rata-rata sudah mengajar, baik guru SD maupun PAUD. Dengan demikian, usia mahasiswa lebih dewasa dibandingkan mahasiswa lulusan SLTA sederajat. Demikian juga dengan jenis kelamin, masuknya mahasiswa S1 PAUD dalam kelompok responden mengakibatkan mayoritas responden adalah berjenis kelamin perempuan. Sedangkan variabel kesukarelaan sudah dinyatakan pada pembahasan sebelumnya bahwa tutorial online adalah bantuan belajar pilihan bagi mahasiswa, mereka dapat dianjurkan untuk mengikutinya namun tidak dilarang untuk tidak menggunakannya.

Sehingga bentuk sederhana konsep UTAUT dalam artikel ini seperti pada Gambar 1.

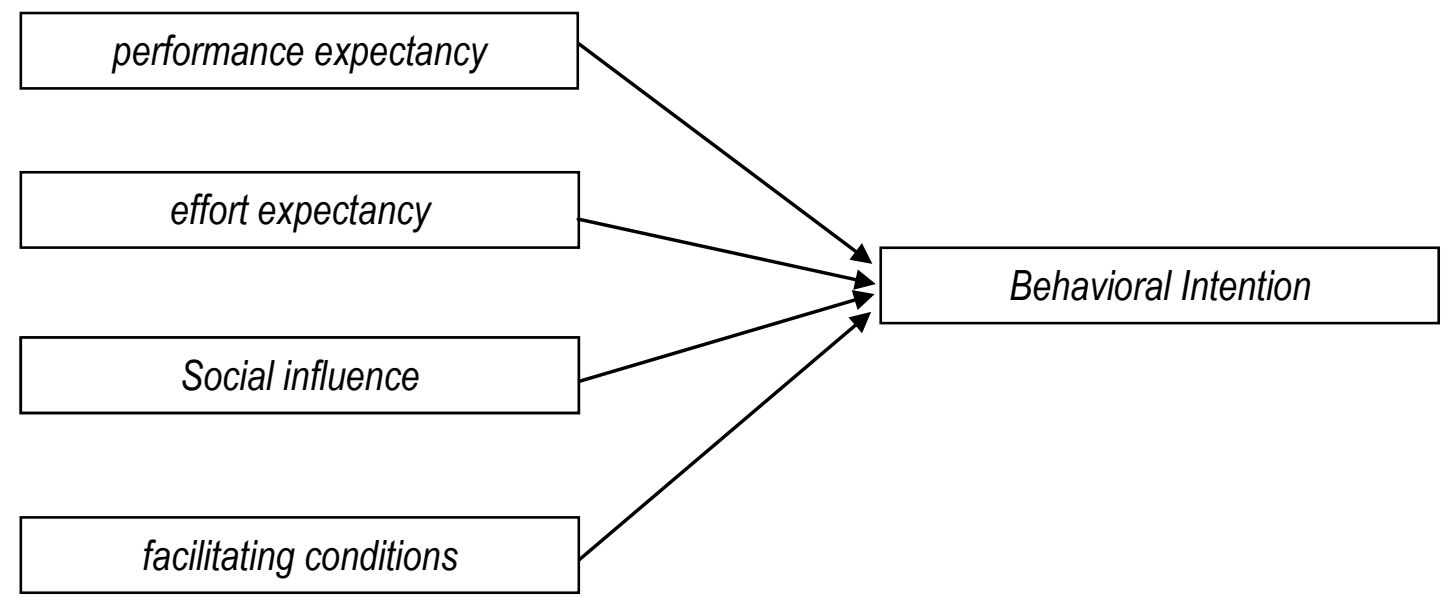

Gambar 1. Kerangka berfikir UTAUT dalam penelitian

\section{METODE}

Dalam UTAUT variabel yang diteliti adalah sebagai berikut (Vinkantesh, 2003):

Performance expectancy merupakan tingkat sejauh mana seseorang meyakini bahwa menggunakan tutorial online akan membantunya mencapai keuntungan kinerja dalam belajarnya. Effort expectancy didefinisikan sebagai tingkat kemudahan terkait dengan penggunaan tutorial online . 
Social influence adalah sebagai tingkat sejauh mana mahasiswa merasakan bahwa orangorang yang dianggapnya penting, percaya bahwa ia seharunya menggunakan tutorial online.

Facilitating conditions didefinisikan sebagai tingkat sejauh mana seseorang meyakini bahwa infrastruktur organisasi dan teknis yang ada mendukung penggunaan sistem.

Dalam konsep dasar model-model user acceptance yang telah dikembangkan, behavioral intention menjadi konstruk intervening (variabel antara) dari hubungan reaksi pengguna atas penggunaan teknologi informasi dengan actual use (use behavior). Menurut Bendi (2013) peran behavioral intention sebagai prediktor use behavior telah secara umum. Karena itu dalam penelitian ini behavioral intention dijadikan variabel terikat. Sejalan dengan Bendi (2013) dalam penelitian ini juga dinyatakan bahwa hubungan antara behavioral intention dan use behavior diabaikan, karena menurutnya berdasarkan banyak penelitian sebelumnya hasilnya akan sama.

Variabel penelitan dalam UTAUT, dioperasionalsasikan dalam pertanyaan berikut (Bendi, 2013) yang telah disesuaikan:

\begin{tabular}{|c|c|}
\hline No & Pernyataan/Pertanyan \\
\hline$A$ & Variabel Performance Expectancy \\
\hline 1 & Menurut saya Tutorial Online berguna dalam studi saya. \\
\hline 2 & $\begin{array}{l}\text { Menggunakan Tutorial Online memungkinkan saya untuk menyelesaikan studi lebih } \\
\text { cepat. }\end{array}$ \\
\hline 3 & Menggunakan Tutorial Online meningkatkan produktivitas saya dalam studi. \\
\hline 4 & $\begin{array}{l}\text { Menggunakan Tutorial Online meningkatkan kesempatan saya untuk mendapatkan } \\
\text { nilai yang baik. }\end{array}$ \\
\hline $\boldsymbol{B}$ & Variabel Effort Expectancy \\
\hline 1 & Saya paham bagaimana caranya menggunakan Tutorial Online. \\
\hline 2 & Mudah bagi saya untuk menjadi terampil dalam menggunakan Tutorial Online. \\
\hline 3 & Menurut saya Tutorial Online mudah digunakan. \\
\hline 4 & Belajar untuk menggunakan Tutorial Online mudah bagi saya. \\
\hline C & Variabel Social Influence \\
\hline 1 & $\begin{array}{l}\text { Orang yang mempengaruhi perilaku saya, berpikir bahwa saya harus menggunakan } \\
\text { Tutorial Online. }\end{array}$ \\
\hline 2 & $\begin{array}{l}\text { Orang yang penting bagi saya, berpikir bahwa saya harus menggunakan Tutorial } \\
\text { Online. }\end{array}$ \\
\hline 3 & Dosen saya telah membantu/mendorong saya untuk menggunakan Tutorial Online. \\
\hline 4 & $\begin{array}{l}\text { Secara umum UT mendukung penggunaan Tutorial Online (misal: dengan } \\
\text { menyediakan komputer, akses internet). }\end{array}$ \\
\hline$D$ & Variabel Facilitating Conditions \\
\hline 1 & $\begin{array}{l}\text { Saya memiliki sumberdaya yang diperlukan untuk menggunakan Tutorial Online } \\
\text { (misal: komputer, laptop, internet) }\end{array}$ \\
\hline 2 & $\begin{array}{l}\text { Saya memiliki pengetahuan yang diperlukan untuk menggunakan Tutorial Online } \\
\text { (misal: tahu menggunakan komputer, tahu menggunakan internet). }\end{array}$ \\
\hline 3 & $\begin{array}{l}\text { Tutorial Online kompatibel dengan sistem lain yang saya gunakan (misal: Tutorial } \\
\text { Online tidak dapat diakses melalui komputer anda, tidak dapat diakses melalui } \\
\text { smartphone/tab anda). }\end{array}$ \\
\hline 4 & Tersedia tenaga khusus yang membantu saya jika mengalami kesulitan mengguna \\
\hline
\end{tabular}




\author{
Tutorial Online. \\ E Variabel Behavioral Intention \\ 1 Saya berniat menggunakan Tutorial Online di semester berikutnya. \\ 2 Saya memperkirakan bahwa saya akan menggunakan Tutorial Online di semester \\ berikutnya. \\ 3 Saya berencana menggunakan Tutorial Online di semester berikutnya. \\ Variabel penelitian diukur menggunakan skala Likert dengan rentang jawaban terdiri dari \\ Sangat Tidak Setuju (STS), Tidak Setuju (TS), Setuju (S), dan Sangat Setuju (SS).
}

\title{
PEMBAHASAN
}

Penyebaran kuesioner secara langsung dari 339 responden sebanyak 108 (32\%) sedangkan $231(68 \%)$ disebarkan melalui email dan telpon. Sebagaimana dalam metode penelitian disebutkan bahwa metode pemilihan responden menggunakan metode random. Untuk mencapai jumlah sampel yang diperlukan digunakan rumus random pada ms excel (rand). Ketika jumlah sampel belum cukup maka diambil lagi sampel dengan metode yang sama. Sedangkan rentang waktu pengambilan data primer dengan instrumen dimulai pada bulan September sampai dengan awal bulan November 2018.

Pengolahan data menggunakan program Predictive Analytics SoftWare (PASW) Statistics 18. Pengolahan meliputi tabel frekuensi, tabel silang,rerata, uji validitas, uji realibilitas, serta analisis regresi sederhana dan regresei berganda.

Menggunakan PASW 18, dilakukan uji validitas terhadap19 item pernyataan/pertanyaan kuesioner. Uji validitas menggunakan correlations pearman. Pada 19 pertanyaan pada kuesioner ditemukan valid ( $r$ hitung $\geq r$ tabel, dg sign. 0,05) dik= $r$ tabel 0,1062.

Sebagaiman disampaikan dalam metode, dengan mempertimbangkan kesalahan atau error yang mungkin terjadi, standar nilai yang digunakan sebesar alpha 0,60. Jika nilai alpha <0,60 maka alat ukur yang tidak konsisten. Berdasarkan perhituangan statistik ditemukan bahwa nilai alpha cronbach 0,865 > dari 0,6 sehingga jika nilai alpha > 0,60 dan semakin mendekati angka satu maka item pertanyaan semakin reliabel/konsisten.

Dari 9 semester pendas, hanya semester 1 dan semester 9 yang tidak menjadi responden pada penelitian ini. Responden paling banyak berasal dari semester dua (88), semester 3 (86), kemudian dari semester 7 (62), sedangkan yang paling sedikit berasal dari semester 6 sebanyak 4 responden dan semester 4 sebanyak 19 responden.

Urutan asal UPBJJ dimana responden berasal yang paling banyak adalah dari mahasiswa Banda Aceh, Palangkaraya, Banjarmasing, Jember dan seterusnya. Hal ini memang sesai dengan besaran jumlah mahasiswa Pendas non TTM yang terdapat di masing-masing UPBJJ. Selain itu, dari 339 responden terdapat 13 orang yang tidak menyebutkan asal UPBJJ.

Pada tabel deskriptif ditemukan rata-rata terendah dari 19 item pernyataan/ pertanyaan pada pertanyaan A1 $(3,392)$ yaitu "Tutorial online berguna dalam studi", sedangkan rerata terendah ditemukan pada D4 $(2,678)$ dengan pertanyaan/pernyataan "Tersedia tenaga khusus yang membantu kesulitan menggunakan tutorial online ". Rerata untuk variabel ditemukan setelah jumlah rerata variabel dibagi dengan jumlah item pertanyaan/pernyataan. Dari empat varibel bebas, dengan rerata tertinggi terdapat pada variabel performance expetancy $(3,121)$, dan terendah pada variabel social influence $(2,853)$. Namun, jika variabel behavioral intention juga masuk dalam perhitungan, maka nilai rerata variabel ini menjadi yang paling tinggi $(3,130)$. 
Setelah melakukan regresi sederhana untuk menguji hipotesa penelitian secara satu persatu, berikut adalah regresi ganda untuk menguji hipotesa beberapa variabel babas secara bersamaan terhadap variabel terikat. Hasil yang diperoleh adalah seperti pada Tabel 1.

Tabel 1. Model Summary Nilai Koefisien Korelasi.

Model Summary

\begin{tabular}{ccccc}
\hline Model & $R$ & $R$ Square & $\begin{array}{c}\text { Adjusted } R \\
\text { Square }\end{array}$ & $\begin{array}{c}\text { Std. Error of the } \\
\text { Estimate }\end{array}$ \\
\hline 1 & $0,582^{\mathrm{a}}$ & 0,339 & 0,331 & 1,46017
\end{tabular}

a. Predictors: (Constant), Facilitating_Conditions, Performance_Expectancy, Effort_Expectancy, Social_Influence

Pada Tabel 1 model summary nilai koefisien korelasi antara variabel Facilitating Conditions, Facilitating Conditions, Performance Expectancy, Effort Expectancy, Social Influence dengan Behavioral Intention adalah 0,582 menunjukkan derajat koefisiensi korelasi yang sedang. $R$ Square disebut koefisien determinasi. Nilai $R$ square adalah 0,339 artinya $34 \%$ variasi yang terjadi terhadap tingggi atau rendahnya Behavioral Intention disebabkan 4 variabel tersebut sedangkan sisanya sebesar $66 \%$ dijelaskan oleh variabel lain.

Tabel 2. ANOVA.

\begin{tabular}{llrrrrr}
\multicolumn{8}{c}{ ANOVA $^{\mathrm{b}}$} \\
\hline \multirow{2}{*}{1} & Model & $\begin{array}{c}\text { Sum of } \\
\text { Squares }\end{array}$ & df & $\begin{array}{c}\text { Mean } \\
\text { Square }\end{array}$ & F & Sig. \\
\hline & Regression & 347,861 & 4 & 86,965 & 40,789 & $0,000^{\mathrm{a}}$ \\
\cline { 2 - 7 } & Residual & 678,009 & 318 & 2,132 & & \\
\cline { 2 - 7 } & Total & 1025,870 & 322 & & &
\end{tabular}

a. Predictors: (Constant), Facilitating_Conditions, Performance_Expectancy, Effort_Expectancy, Social_Influence

b. Dependent Variable: Behavioral_Intention

Tabel 2, anova menampilkan $F_{\text {hitung }}=40,789 . F_{\text {tabel }}$ pada taraf signifikansi $5 \%$ dari df $(3,335)$ adalah 2,631. Dengan demikian dapat dikatakan bahwa $F_{\text {hitung }}(40,789)>F_{\text {tabel }}(2,63)$. Sehingga, H5 diterima yaitu Facilitating Conditions, Facilitating Conditions, Performance Expectancy, Effort Expectancy, Social Influence mempunyai pengaruh terhadap behavioral intention. Sedangkan Ho yang menyatakan bahwa Facilitating Conditions, Facilitating Conditions, Performance Expectancy, Effort Expectancy, Social Influencetidak mempunyai pengaruh terhadap behavioral intention, ditolak. 
Tabel 3. Regresi Ganda Empat Variabel

\begin{tabular}{|c|c|c|c|c|c|c|}
\hline \multirow{3}{*}{\multicolumn{2}{|c|}{ Model }} & \multicolumn{3}{|c|}{ Coefficients $^{a}$} & \multirow{3}{*}{$t$} & \multirow{3}{*}{ Sig. } \\
\hline & & \multicolumn{2}{|c|}{$\begin{array}{l}\text { Unstandardized } \\
\text { Coefficients }\end{array}$} & $\begin{array}{c}\text { Standardized } \\
\text { Coefficients }\end{array}$ & & \\
\hline & & $\mathrm{B}$ & Std. Error & Beta & & \\
\hline \multirow[t]{5}{*}{1} & (Constant) & $-0,347$ & 0,773 & & $-0,450$ & 0,653 \\
\hline & Performance_Expectancy & 0,159 & 0,046 & 0,178 & 3,485 & 0,001 \\
\hline & Effort_Expectancy & 0,075 & 0,050 & 0,079 & 1,497 & 0,135 \\
\hline & Social_Influence & 0,111 & 0,054 & 0,110 & 2,045 & 0,042 \\
\hline & Facilitating_Conditions & 0,448 & 0,060 & 0,390 & 7,422 & 0,000 \\
\hline
\end{tabular}

a. Dependent Variable: Behavioral_Intention

Pada Tabel 3 , regresi ganda empat variabel secara bersamaan dan dengan ketentuan signifikansi $<0,05$ dan nilai t tabel $=1,967$, ditemukan bahwa berdasarkan tabel coefisien Performance Expectancy (sig. 0,001) (t 3,485) $=\mathrm{t}$ hitung >t tabel. Effort Expectancy $($ sig. 0,135), (t 1,497) $=\mathrm{t}$ hitung $<\mathrm{t}$ tabel, Social Influence $($ sig. 0,042),$(t 2,045)=\mathrm{t}$ hitung $>\mathrm{t}$ tabel, dan Facilitating Conditions (sig. 0,000), (t 7,442) = thitung $>t$ tabel.

Dengan demikian pengaruh bersama-sama variabel bebas terhadap variabel terikat berbeda ketika variabel dihitung satu-persatu. Secara bersama-sama diketahui bahwa Facilitating conditions (sig. 0,000) mempunyai pengaruh paling signifikan terhadap behavioral intention. Setelahnya, pengaruh signifikan diberikan oleh variabel Performance expectancy $(0,001)$. Pengaruh lebih lemah oleh variabel Social influence $(0,042)$. Sedangkan Sedangkan variabel Effort expectancy $(0,135)$ tidak mempunyai pengaruh signifikan terhadap behavioral intention.

Berdasarkan tabel coefisient, signifikansi masing-masing variabel digambarkan sebagaimana bagan seperti pada Gambar 2.

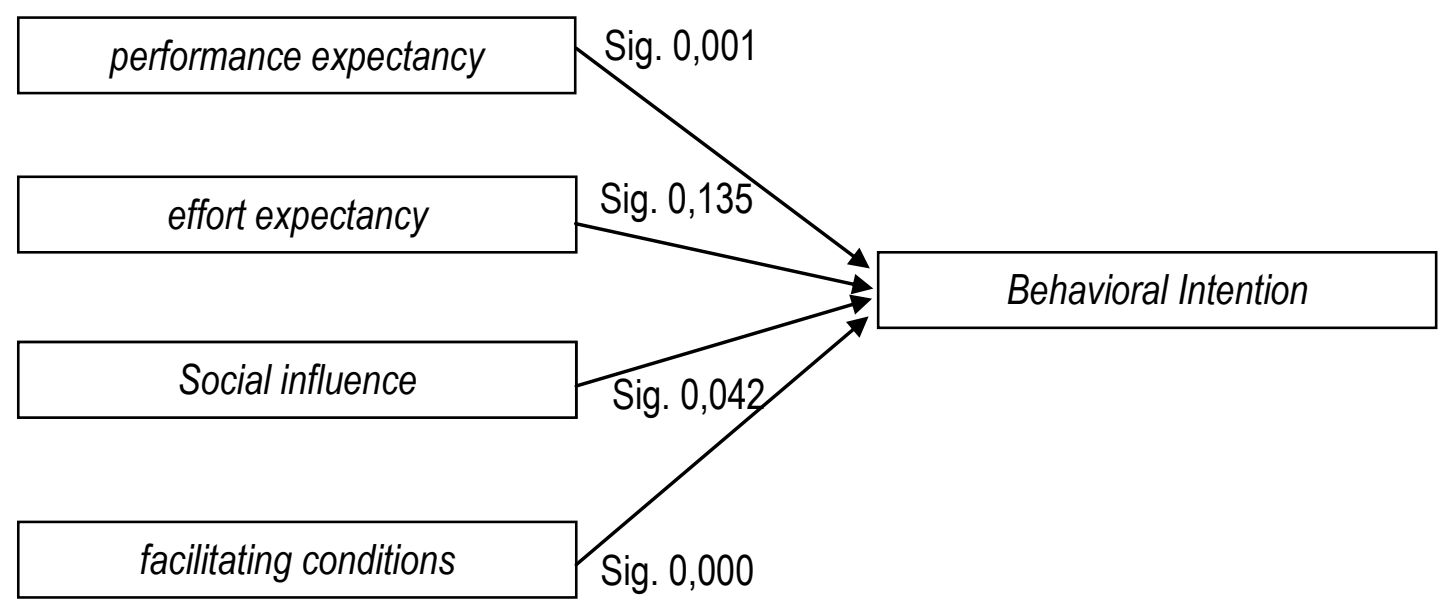

Gambar 2. Signifikansi masing-masing variabel

Tutorial online (Tuton) ini merupakan bantuan belajar dengan menggunakan internet. Oleh karena itu untuk mengikutinya mahasiswa harus mempunyai koneksi internet, sehingga ia dapat berinteraksi dengan tutor dan sesama mahasiswa secara langsung. Dibukanya program studi S1 
PGSD dan PGPAUD Non TTM, memiliki konsekuensi bahwa mahasiswa tidak memperoleh layanan bantuan belajar tutorial tatap muka. Dengan demikian, mahasiswa diberikan kebebasan berupa pilihan untuk belajar mandiri (tanpa bantuan belajar sama sekali) atau mengikuti tutorial online. Variabel ini dapat dikatakan sebagai volunter atau bukan kewajiban bagi mahasiwa untuk ikut tutorial online . Karena memang seperti program-program lain, tidak ada kewajiban bagi mahasiswa UT untuk ikut salah satu bantuan belajar yang disediakan. Karena mahasiswa pada dasarnya diharapkan mampu belajar secara mandiri. Namun meskipun demikian, UT mempunyai kewajiban untuk menyediakan fasilitas bantuan belajar jika ada diantara mahasiswa yang mengalami kesulitan dalam memahami konsep tertentu.

untuk berprilaku menggunakan tutorial online pada mahasiswa diukur dengan pernyatan niat, perkiraan Niat rencana menggunakan tutorial online semester berikutnya. Menurut Maruping, et al (2017) penelitian tentang penggunaan teknologi informasi, telah menjadi salah satu aliran penelitian yang paling matang dalam ilmu literatur sistem informasi, terutama didasarkan pada kerangka intensionalitas. Niat perilaku untuk menggunakan tenknologi dianggap sebagai satu-satunya determinan utama dari adopsi dan penggunaannya. Dalam penelitian ini rata-rata responden menyatakan bahwa mereka setuju dan untuk menggunakan tutorial online pada semester berikutnya.

Namun niat perilaku menggunakan tutorial online tersebut dipengaruhi oleh variabel-variabel. Dalam penelitian ini 4 variabel yang diasumsikan berpengaruh pada variabel niat perilaku adalah, harapan kinerja (performance expectancy), harapan usaha (effort expectancy), pengaruh sosial (social influence), dan kondisi pendukung (facilitating conditions). Pada analisa data yang ditemukan, peneliti menguji dengan dua kali proses. Proses pertama adalah melakukan regresi sederhana pada masing-masing variabel bebas dan variabel terikat, selanjutnya proses dilakukan dengan perhitungan regresi ganda pada semua variabel bebas dan variabel terikat. Temuan menarik pada proses ini menghasilkan hasil yang berbeda, namun hal tersebut saling mendukung dan menguatkan.

Harapan kinerja (Performance expectancy) mempunyai pengaruh yang signifikan terhadap niat perilaku (behavioral intention). Responden menyatakan dalam penelitian ini bahwa mereka memiliki harapan dengan mengikuti tutorial online akan sangat membantu studi yang mereka jalani. Hal ini juga terbukti dengan rata-rata frekuensi yang ditemukan dalam data penelitian. Ketiadaan bantuan belajar tutorial tatap muka pada mahasiswa S1 PGSD dan S1 PGPAUD non TTM, membuat mereka berharap besar dengan tutorial online. Selain itu, dengan mengikuti tutorial online mereka berharap dapat menyelesaikan studi tepat pada waktunya selama 9 semester, dapat membantu produktivitas belajar, dan yang terakhir berharap untuk mendapatkan nilai yang baik saat ujian akhir semester.

Temuan menarik adalah ketika harapan kinerja ditemukan mempunyai hubungan signifikan dana niat perilaku, namun hasil sebaliknya pada variabel selanjutnya yaitu harapan usaha (effort expectancy). Pada anova di regresi sederhana variabel ini sudah ditemukan memiliki hubungan yang lemah dengan niat perilaku, kemudian saat bersama-sama variabel lain dihitung pada regresi berganda bahkan ditemukan tidak signifikan (H2 ditolak). Variabel ini terdiri dari pemahaman penggunaan tutorial online, kemudahan terampil menggunakan tutorial online, serta kemudahan untuk menggunakan secara aktual tutorial online. Temuan ini tentu tidak menyatakan bahwa tutorial online meyulitkan responden, namun temuan ini mengindikasikan bahwa kemudahan dan kesulitan menggunakan tutorial online tidak mempengaruhi niat mahasiswa untuk menggunakan tutorial online. Hal ini justru menguatkan bahwa mahasiswa atau responden pada dasarnya menginginkan hasil yang baik (performance) dengan mengikuti bantuan belajar tutorial online meskipun bagi mereka 
bantuan belajar ini merupakan hal yang baru bagi mereka. Hal ini juga didukung dengan rata-rata frekuensi variabel. Pada effort expectancy, rerata nya lebih baik dari social influence meskipun lebih kecil dari performance expectancy. Temuan ini berbeda dengan hasil penelitian lain yang sejenis, seperti penelitian Nur (2017) tentang penggunaa e-learning pada mahasiswa Halueleo, Rahmi (2017) pada penelitian Sistem Informasi Dosen dan Pegawai Universitas Muhammadiyah Bengkulu. Pada kedua penelitian serupa tersebut ditemukan bahwa semua varibel bebas, tak terkecuali effort expectancy mempengaruhi secara signifikan terhadap perialaku penggunannya.

Perlu juga untuk menjadi perhatian bagi kami sebagai peneliti bahwa pada pernyataan tentang kemudahan untuk terampil menggunakan Tutorial Online, dari 339 responden sebanyak 8 orang tidak memberikan jawaban. Kemudian pada anggapanbahwa Tutorial Onlinemudah digunakan sebanyak 4 responden tidak menjawab. Temuan ini dapat menjadi salah satu sebab variabel effort expectancy tidak berpengaruh signifikan terhadap niat perilaku menggunakan. Sehingga kami sebagai peneliti menafsirkan data tersebut dengan dua hal mahasiswa menganggap bahwa mudah dan tidaknya tutorial online tidaklah penting atau bisa juga mahasiswa tidak mengerti sama sekali menggunakan tutorial online sehingga mereka tidak mampu menjawab mudah atau sulit dalam menggunakannya. Namun asumsi yang terakhir harus diabaikan karena dalam pemilihan responden dan sampel penelitian, kami tidak mungkin mengambil responden tentang penggunaan tutorial online jika responden tidak pernah menggunakan atau tidak mengerti sama sekali menggunakannya. Data pengambilan responden berdasarkan data hits tutorial online dari Pusat Bantuan Belajar (PBB) Universitas Terbuka.

Pada variabel pengaruh sosial (social influence) ditemukan berpengaruhi signifikan terhadap perilakuk pengguna. Namun demikiam, pada penelitian variabel pengaruh sosial menjadi temuan menarik lainnya. Pada variabel ini lebih mengindikasikan pengaruh orang-orang di sekeliling mahasiswa untuk menggunakan tutorial online. Meskipun variabel ini berpengaruh terhadap niat perilaku menggunakan tetapi berdasarkan data frekuensi ditemukan bahwa social influence memiliki rerata paling rendah yaitu 2,853 .

Orang-orang berpengaruh pada variabel dapat berupa teman, pimpinan, orang terdekat dalam keluarga, serta dosen atau tutor. Niat perilaku menggunakan tutorial onlinedipengaruhi oleh orang-orang tersebut, meskipun dengan tingkat hubungan variabel yang lemah. Temuan ini dapat mengisyaratkan bahwa mahasiswa UT adalah mahasiswa yang mandiri, tidak tergantung pada orang lain dalam menggunakan tutorial online. Sehingga ada variabel lain selain orang di sekeliling responden yang menjadi penentu penggunaan tutorial online. Kemandirian mahasiswa dalam sistem pembelajaran jarak jauh adalah modal kesuksesan dalam studi. Sehingga dalam berbagai kesempatan UT selalu memberikan penekanan terhadap kemandirian tersebut. Penekanan pertama kali bagi mahasiswa untuk belajar mandiri adalah saat orientasi studi mahasiswa baru (OSMB), kemudian mulai 2018.2 mahasiswa diberikan Pelatihan Edukasi Keterampilan Belajar Mandiri (EKBM).

Kemudian variabel facilitating conditions, ditemukan satu item pertanyaan dengan frekuensi paling rendah dari 19 pernyataan yang diberikan. Pernyataan mengenai tersedianya tenaga khusus untuk membantu mahasiwa ketika mengalami kesulitan menggunakan Tutorial Online. Data rata-rata dari pertanyaan tersebut berjumlah 2,678, jawaban ini mengindikasikan bahwa mahasiswa memerlukan tenaga khusus dari UT yang mampu memberikan solusi mereka ketika mengalami kesulitan saat tutorial online. Dari UT Pusat hingga setiap UPBJJ UT mempunyai hotline untuk menangani semua keluhan mahasiswa. Keluhan-keluhan tersebut diantaranya adalah mengenai tutorial online. Bahkan beberapa daerah di UPBJJ tertentu telah di dirikan Salut (Sentra layanan UT). 
Diharapkan dengan adanya media komunikasi hotline resmi dari UT dan UPBJJ serta komunikasi langsung ke personal yang dianggap mampu membantu mahasiswa.

Mengenai tersedianya sarana dan tenaga pendukung dalam temuan penelitian ini sesuai temuan penelitian Sudarwo, dkk (2018) bahwa ketersediaan sarana prasarana belajar dapat memberikan pengaruh positif pada kemandirian mahasiswa. Namun demikian, kewajiban untuk melengkapi sarana yang mendukung tutorial online bukan hanya kewajiban UT namun mahasiswa juga diharapkan mampu memenuhi perangkat perlengkapan yang dapat menunjang pembelajarannya. Hal ini ditanyakan pada item D-1 bahwa "mahasiswa memiliki sumber daya yang diperlukan untuk menggunakan tutorial online". Pernyataan tersebut kemudian dijawab setuju sebanyak 189 responden $(55,8 \%)$ dan sangat setuju 108 responden $(31,9 \%)$. Sehingga, dari hasil tersebut dapat dikatakan bahwa mayoritas mahasiswa responden memiliki alat pendukung untuk tutorial online.

Selanjutnya, pada data niat perilaku (behavioral intention) mahasiswa untuk menggunakan tutorial online pada semester berikut ditemukan data bahwa mayoritas responden memiliki niat dan rencana untuk mengikuti tutorial online. Namun demikian, mahasiswa yang menyatakan sangat tidak setuju dan tidak setuju dari tiga pernyataan rata-rata di atas 10\% mahasiswa. Jika dihitung, dari 339 responden maka sekitar 33 responden menyatakan tidak akan mengikuti tutorial online semester berikutnya. Angka tersebut akan menjadi lebih besar jika jumlah sampel terjadi pada populasi penelitian, maka 30\% dari 2.225 yaitu 667 mahasiswa memiliki rencana tidak mengikuti tutorial online. Meskipun kebijakan tutorial di UT pada saat ini masih bersifat sukarela tidak wajib diikuti mahasiswa. Namun bantuan belajar berupa tutorial online dapat menjadi bantuan bagi mahasiwa untuk mempermudah memahami materi mata kuliah selama menempuh pendidikan. Walaupun dalam sebuah penelitian keikutsertaan mahasiswa dalam tutorial online tidak berbanding lurus dengan nilai ujian akhir mahasiswa pesertanya (Wahyuningsih, 2017).

Sangat penting untuk memperhatikan tingkat penerimaan responden yaitu mahasiswa S1 PGSD dan PGPAUD tentang teknologi yang mereka anggap baru, seperti layanan tutorial online. Menurut Davis (1987) penerimaan pengguna merupakan indikator menentukan sukses dan tidaknya teknologi diterima dalam organisasi. Karena keputusan individu atau organisasi untuk menggunakan atau tidak menggunakan suatu teknologi komunikasi akan berdampak pada kinerja organisasi.

Universita Terbuka sebagai pelopor pendidikan tinggi jarak jauh, merupakan perguruan tinggi menuju cyber campus. Di era revolusi industri 4.0 kalobrasi teknologi dan pendidikan harus lebih memperhatikan inovasi dan kemutakhiran teknologi. Namun kebaruan yang diterapkan harus melihat bagaimana pengguna menerima teknologi baru yang ditawarkan. Banyak faktor yang menjadi sebab gagalnya penerimaan dan adopsi teknologi baik internal maupun eksternal. Lebih awal memprediksi faktor-faktor yang dapat mengakibatkan kegagalan dan hambatan penerimaan mahasiswa menggunakan tutorial online akan lebih baik dari pada berakibat tidak tercapainya visi, misi dan tujuan institusi Universitas Terbuka sebagai cyber campus berkelas dunia.

\section{SIMPULAN DAN SARAN}

Dari hasil penelitian dan pembahasan dapat disimpulkan sebagai berikut:

1. Diketahui bahwa Facilitating conditions (sig. 0,000) mempunyai pengaruh paling signifikan terhadap behavioral intention. Setelahnya, pengaruh signifikan diberikan oleh variabel Performance expectancy $(0,001)$. Pengaruh lebih lemah oleh variabel Social influence $(0,042)$. Sedangkan Sedangkanvariabel Effort expectancy $(0,135)$ tidak mempunyai pengaruh signifikan terhadap behavioral intention. 
2. Tidak signifikannya variabel harapan usaha (effort expectancy) tidak menyatakan bahwa tutorial online menyulitkan responden. Karena berdasarkan data tabel frekuensi temuan ini mengindikasikan bahwa kemudahan dan kesulitan menggunakan tutorial online tidak mempengaruhi niat mahasiswa untuk menggunakan tutorial online.

3. Ditemulan juga bahwa mahasiswa menganggap perlu adanya tenaga khusus yang dapat membimbing mereka dalam kesulitan yang ditemuai saat mengikuti tutorial online. selain, itu mayoritas responden memiliki niat dan rencana untuk mengikuti tutorial online semester berikutnya. Namun, responden tidak akan mengikuti tutorial online semester berikutnya rata-rata sebesar $10 \%$. Jika ditarik dalam jumlah populasi maka mereka yang menyatakan tidak akan ikut tutorial online maka jumlah akan lebih besar.

\section{Saran}

Secara akademis peneliti menyarankan bahwa konsep analisis menggunakan UTAUT terhadap penerimaan inovasi sebuah teknologi merupakan teori populer dan terus berkembang hingga sekarang. Hal tersebut terjadi seiring semakin cepatnya berkembangan teknologi komunikasi informasi dan semakin luasnya penerimaan dan penggunaan masyarakat terhadapnya.Dinamika perubahan dan saling melengkapi konsep-konsep teori terus terjadi karena semakin luasnya penggunaan teknologi informasi di seluruh aspek kehidupan, salah satunya adalah aspek pendidikan khususnya pendidikan jarak jauh. Penelitian pada bidang ini selalu memunculkan temuan-temuan menarik untuk terus ditelaah dan diteliti.

Selanjutnya secara praktis dan institusional, peneliti menyarankan bahwa bagi mahasiswa sarjana dan diploma di Universitas Terbuka, tutorial online merupakan salah satu bantuan belajar yang bersifat sukarela. UT memiliki kewajiban untuk menyediakan namun mahasiswa tidak ada kewajiban untuk mengikutinya. Kondisi ini membutuhkan motivasi yang tinggi bagi mahasiswa sarjana dan diploma. Sehingga diperlukan dorongan motivasi yang lebih baik agar mahasiswa tetap termotivasi untuk terus ikut, seperti menaikkan kontribusi tutorial online terhadap UAS, atau motivasi lain yang dianggap baik bagi mahasiswa.

Selain itu, termasuk salah satu menjadi temuan penelitian adalah perlunya tenaga khusus yang dapat membimbing mahasiswa khususnya tutorial online sedang berlangsung. Solusi bimbingan dapat melalui media komunikasi sehingga dapat dijangkau oleh mahasiswa dimanapun dan kapanpun. Selain itu, kebijakan pelatihan seperti Pelatihan Edukasi Belajar Mandiri (EKBM) sangat tepat untuk untuk lebih memantapkan kemampuan mahasiswa khususnya berkaitan dengan layanan online UT, meskipun efektifitas kegiatan ini masih perlu diteliti namun setidaknya telah memberikan informasi penting tentang layanan tutorial online kepada mahasiswa baru Universitas Terbuka.

\section{REFERENSI}

Ajzen, I. \& Fishbein, M. (1980). Understanding Attitudes and Predicting Social Behavior. Englewood Cliffs, New Jersey: Prentice Hall.

Bendi, R., \& Andayani, S. (2013). Penerapan Model Utaut Untuk Memahami Perilaku Pengguna Sistem Informasi Akademik. Jurnal HOAQ Teknologi Informasi, 2(1), 144-151.

Davis, Gordon B. (1993). Kerangka Dasar Sistem Informasi Manajemen. Terjemahan, Seri Manajemen 90-A. Jakarta: PT. Pustaka Binaman Pressindo.

Davis, Ivor K. (1987). Pengelolaan Belajar, Penerjemah Sudarsono S., dkk., Jakarta: CV.Rajawali dan PAU-UT. 


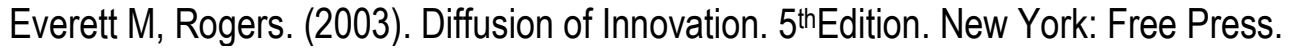
FKIP Universitas Terbuka. (2017).Pedoman Sipas Non TTM FKIP Universitas Terbuka.

Frans, Y. A., \& Aisyah, S. (2018). Pengaruh Kualitas Layanan Tutorial Online Terhadap Kepuasan Dan Loyalitas Mahasiswa FISIP-UT. Jurnal Pendidikan Terbuka Dan Jarak Jauh, 19(1), 1-12. Handayani, T., \& Sudiana, S. (2017, January). Analisis Penerapan Model Utaut (Unified Theory Of Acceptance And Use Of Technology) Terhadap Perilaku Pengguna Sistem Informasi (Studi Kasus: Sistem Informasi Akademik pada STTNAS Yogyakarta). In Prosiding Seminar Nasional ReTII.

King, W. R., \& He, J. (2006). A meta-analysis of the technology acceptance model. Information \& Management, 43, 740-755. https://doi.org/10.1016/i.im.2006.05.003

Maruping. et al. (2017). Going Beyond Intention Integrating Behavioral Expectation into the Unified Theory of Acceptance and Use of Technology. Journal of the Association for Information Science and Technology, Vol.68 Issue 3, 2017.

Nasir, M. (2013, June). Evaluasi penerimaan teknologi informasi mahasiswa di Palembang menggunakan model UTAUT. In Seminar Nasional Aplikasi Teknologi Informasi (SNATI) (Vol. 1, No. 1).

Nur, M. N. A., Faslih, A., \& Nur, M. N. A. (2017). Analysis of Behaviour of E-learning Users by Unified Teory of Acceptance and Use of Technology (UTAUT) Model A Case Study of Vocational Education in Halu Oleo University. Jurnal Vokasi Indonesia, 5(2).

Pacey, Arnold. The Culture of Technology; Massachusetts: MIT Press, 2000.

Rahmi, Y., Soedijono, B., \& Al Fatta, H. (2017). Analisis Penerapan Sistem Informasi Dosen Dan Karyawan (Simdoskar) Menggunakan Model Unified Theory Of Acceptance And Use Of Technology (UTAUT) Terhadap Perilaku Pengguna. Informasi Interaktif, 2(2), 109-117.

Saeed, Rashid, et. al. 2014. Impact of Service Quality on Customer Loyalty in Islamic Banking Sector of Pakistan: A Mediating Role of Customer Satisfaction. Journal of Basic and Applied Scientific Research. Vol. 4, No. 2.

Sedana, I. G. N. (2009). Penerapan model UTAUT untuk memahami penerimaan dan penggunaan learning management system studi kasus: Experential e-learning of Sanata Dharma University. Jurnal Sistem Informasi, 5(2), 114-120.

Sudarwo, dkk (2018). Pengaruh Sarana Belajar dan Motivasi Belajar terhadap Kemandirian Belajar Mahasiswa (Studi Empirical pada Mahasiswa Beasiswa Bidikmisi UPBJJ-UT Ternate. Jurnal Pendidikan. Universitas Terbuka. Vol 19 no. 2.

Vinkatesh, V., M.G. Morris, G.B. Davis, F.D. Davis. (2003). User acceptance of information technology: toward a unified view, MIS Quarterly, vol. 27, pp. 425-478.

Wahyuningsih, S. S., Rusli, Y., \& Bintarti, A. (2017). Aksesibilitas mahasiswa pada tutorial online program studi perpustakaan. Jurnal pendidikan terbuka dan jarak jauh, 16(1), 29-38.

Wardoyo \& Karyanto. (2011). Tingkat Pemanfaatan Sumber Belajar Berbasis Online bagi Mahasiswa Universitas Terbuka Program Non-Pendas. Hasil Penelitian. Universitas Terbuka. Malang. 


\section{INDEKS JURNAL PENDIDIKAN TERBUKA DAN JARAK JAUH TAHUN 2018}

acceptance and use of technology, 119

affordance of technology, 31

ASEAN Studies Graduate Program, 31, 32, 33, 36

COI Framework, 19, 30

community of inquiry, 19, 20

constrctivism, 13

courses, 35, 87

creative, 58

descriptive study, 38

development, 13, 14, 17, 31, 32, 36, 55, 87

discussions, 58

Distance Learning, 30, 65, 66

education, 1, 13, 14, 15, 19, 31, 32, 33, 35, 36, 38, 52, 71, 87

e-learning, 13, 14, 31, 33, 90, 91, 92, 128, 131

gender, 33, 36, 38, 39, 43, 44, 45, 46, 47, 48, 50, 120

government, 33,87

innovative, 58

internet usage, 1

learning theory, 13, 14, 15, 17

media convergence, 52

media interpersonal communication, 52

online learning, 13, 14, 15, 19, 30, 66

online tutorial, 1, 13, 14, 58, 65, 99

online tutorial service, 1

online tutorials, 1, 65, 99

Open Educational Resources, 65, 66, 71, 72

Policy Implementation, 73

practice, 30,87

questions, 1, 15, 58, 65

S1 PGSD and PGPAUD, 119

science subject, 38

social presence, 19, 30

stress, 38, 51

student satisfaction, 99

student services, 99

students satisfactory, 1

translation, 65

tutorial, $1,2,3,6,7,9,10,13,14,16,53,58,59,60,61,62,63,65,66,74,76,83,90,91,92,99$, $100,107,109,110,112,113,114,115,116,117,118,119,120,121,122,123,124,127$, $128,129,130,131$ 
tutorial tasks, 58

tutorials, 15, 58, 99, 119

UPOU, 31, 32, 33, 35

UTAUT, 119, 120, 121, 122, 123, 130, 131

virtual learning, 52 


\section{INDEKS PENULIS JURNAL PENDIDIKAN TERBUKA DAN JARAK JAUH \\ TAHUN 2018}

Afriani S S, 65

Anfas, 38, 39, 51

Anis Surtiani, 13

Benny A Pribadi, 13

Djoko Rahardjo, 99

Dwi Kristanti, 73

Enceng, 87

Fitri Amilia, 58

Ichwan, 13

Irawan, 102, 118, 119

Irfandi Buamonabot, 38

Jean A Saludadez, 31

Majidah, 99

Mody Gayes Tuliabu, 119

Mohbir Umasugi, 38

Niki Raga Tantri, 19

Nur Asiah, 119

Raden Sudarwo, 38

Siti Aisyah, 1, 87

Sri Sediyaningsih, 52

Sri Suharmini, 99

Yudith A Frans, 1 
INDEKS PENYUNTING JURNAL PENDIDIKAN TERBUKA DAN JARAK JAUH TAHUN 2018

\author{
Daryono \\ Purwanto \\ Oos Anwas \\ Tri Darmayanti \\ Asmawi Zainul \\ Maximus Gorky Sembiring \\ Muhammad Husni Arifin \\ M. Atwi Suparman \\ Adhi Susilo \\ Herman \\ Widyasari \\ Santi Dewiki \\ Mohamad Toha \\ Ida Malati Sadjati
}

